\title{
Tree nutrition of Norway spruce as modified by liming and experimental acidification at the Höglwald site, Germany, from 1982 to 2004
}

\author{
Christian HUBER*, Wendelin WeIs, Axel GöTTLEIN \\ Fachgebiet für Waldernährung und Wasserhaushalt, Department für Ökologie, WZW, TU München, Am Hochanger 13, 85354 Freising, Germany
}

(Received 31 October 2005; accepted 23 March 2006)

\begin{abstract}
From 1982 to 2004 the elemental concentrations of current, current+1, and current +2 year old needles of a mature spruce stand were investigated at the $\mathrm{N}$-saturated, acidified, but healthy Höglwald site. The control was compared with a liming, experimental acid irrigation, acid irrigation + liming, normal irrigation, and normal irrigation + liming treatment. Liming was performed in 1984, and irrigation from 1984-1990. High year to year variations were found for most of the elements in all treatments, especially for K ("deficient" to "high"). Despite the N saturation of the ecosystem, needles showed no N-overfeeding of the trees. $\mathrm{N}, \mathrm{Mg}, \mathrm{K}, \mathrm{Fe}$ concentrations showed no clear treatment effects. Twenty years after liming a lowered $\mathrm{P}$ availability is indicated, which was more pronounced in older needles. Ca concentrations increased after liming, while Al decreased. The elemental concentrations of the acid irrigated treatment did not differ significantly from the normal irrigated or control treatment.
\end{abstract}

liming / long term study / soil acidification / spruce / tree nutrition

Résumé - Modifications de la nutrition forestière par acidification expérimentale et chaulage dans le site du Höglwald (Allemagne) entre 1982 et 2004. Les concentrations en éléments minéraux des aiguilles de l'année, et celles âgées d'un an et de deux ans ont été mesurées entre 1982 et 2004 dans un peuplement d'épicéa adulte, saturé en azote et acidifié, mais sain, du site de Höglwald. Ce témoin a été comparé avec les traitements suivants : chaulage, irrigation acide expérimentale, irrigation acide + chaulage, irrigation normale, irrigation normale + chaulage. de fortes variations interannuelles ont été observées pour tous les éléments et tous les traitements, particulièrement pour $\mathrm{K}$ (teneurs déficientes à élevées). Malgré la saturation en azote de l'écosystème, les aiguilles n'indiquaient pas d'excès de nutrition azotée. Les concentrations en $\mathrm{N}, \mathrm{Mg}, \mathrm{K}$ et Fe n'ont pas été affectées par les traitements. Vingt années après le chaulage, une plus faible disponibilité en P est indiquée, spécialement par les aiguilles agées. Les concentrations en Ca des aiguilles augmentent après chaulage, et celles en al baissent. Les concentrations mesurées dans le traitement d'irrigation acide ne diffèrent pas de celle des traitements irrigation normale ou du témoin.

chaulage / étude à long terme / acidification des sols / épicéa / nutrition forestière

\section{INTRODUCTION}

Forest liming has been practised increasingly in Central and Northern Europe since the 1980s as a countermeasure against the destabilisation of forests and the decrease in water quality due to acid rain and soil acidification [39, 40]. The expected positive effects of forest liming are the deacidification of soil and seepage water, and the increase in $\mathrm{Ca}$ and $\mathrm{Mg}$ supply of the soil [2], which may have been decreased by various processes of soil acidification [4]. However, negative effects have also occurred: emission of $\mathrm{CO}_{2}$ due to the loss of organic matter [22,32], $\mathrm{NO}_{3}^{-}$leaching [25], and reduced tree growth $[31,36]$. Therefore, forest liming is still controversial in Central and Northern Europe [19, 24, 27, 31, 32, 36, 41] and the various foci and interpretations of the findings of the acidification/liming problems have resulted in very diverse policies, especially in the German states [19]. However, there is still little information about the long-term effects of liming on the

*Corresponding author: Huber@forst.tu-muenchen.de nutrient concentrations in the leaves, although this criterion is widely used for evaluation of the nutrient status, soil nutrient availability, and as an indicator of forest health [13]. In general, long-term studies on the nutrient status are rare [38]. A broader assessment of forest nutrition of forests in Europe was not started until the Level II programme in 1994 [29]. In the 1980s, a forest liming and acidification experiment was established at the Höglwald site [26], Southern Germany, and tree nutrition was monitored until 2004. In this paper, we will show the time trends of nutrient concentrations in the needles.

\section{MATERIALS AND METHODS}

\subsection{Site and stand description}

The Höglwald is a long-term ecological monitoring and experimentation site $[19,26]$. The small forest district (370 ha) is situated on a flat hilltop at an altitude of $540 \mathrm{~m}$ above sea level, about $70 \mathrm{~km}$ north of the Alps and $50 \mathrm{~km}$ west of Munich at $11^{\circ} 06^{\prime} \mathrm{E}$ and $48^{\circ} 17^{\prime} \mathrm{N}$. 
The soil is a Parabrown Earth strongly acidified in the topsoil. The mineral soil is covered by an organic layer of 6 to $8 \mathrm{~cm}$ (moder). In the organic layer the base saturation is relatively high (40 to 80\%), but the $\mathrm{pH}$ values are extremely low with a minimum in the Oh horizon of $2.75(\mathrm{KCl})$. The base saturation in the A horizon $(0-40 \mathrm{~cm})$ is only $5-10 \%$, and the $\mathrm{Al}$ saturation is high (80-90\%). The $\mathrm{pH}$ values of $4.0(\mathrm{KCl})$ indicate the aluminium buffer range. In the B horizon $(40-130 \mathrm{~cm})$, the base saturation increases with depth as well as $\mathrm{pH}$ values. There is a great subsoil reservoir of exchangeable $\mathrm{Ca}^{2+}$ and $\mathrm{Mg}^{2+}$ accessible to the deep reaching vertical root system, while the $\mathrm{K}^{+}$supply of the CEC is relatively short [26]. The $\mathrm{C} / \mathrm{N}$ ratio in the forest floor varies between 23 and 27 . The productivity of the stand is not limited by the availability of $\mathrm{N}$ - the site is $\mathrm{N}$-saturated: throughfall input is about $30 \mathrm{~kg} \mathrm{~N} \mathrm{ha}^{-1} \mathrm{yr}^{-1}$ [34], adsorption of ammonia in the forest floor seems to be a significant input [17, 18]; the excess $\mathrm{N}$ causes high $\mathrm{NO}_{3}^{-}$leaching [20] and volatilisation of trace gases [6]. The stands are fully stocked, vigorously growing mature Norway spruce plantations (Picea abies (L.) Karst). Before the experimental treatment was started (1983), the spruce stand had the following dendrometrical characteristics: 76 years old, a density of 603 trees per ha, a basal area of $70.9 \mathrm{~m}^{2} \mathrm{ha}^{-1}$, a growing stock of $1124 \mathrm{~m}^{3} \mathrm{ha}^{-1}$, a mean breast height diameter of $38.7 \mathrm{~cm}$, the mean height was $33.8 \mathrm{~m}$, and the dominant height was $35.9 \mathrm{~m} \mathrm{[26].} \mathrm{More}$ information about the dendrometrical characteristics of the treatments is given by Huber et al. [19].

\subsection{Experimental treatments}

The treatments are part of a larger experimental set-up [26]. In an area with very uniform stand and site conditions, the following treatments were made:

$\begin{array}{ll}\text { A 1 } & \text { control; } \\ \text { B 1 } & \text { acid irrigation; } \\ \text { C 1 } & \text { normal irrigation; } \\ \text { A 2 } & \text { liming; } \\ \text { B 2 } & \text { liming with acid irrigation; } \\ \text { C 2 } & \text { liming with normal irrigation. }\end{array}$

The area of each experimental treatment is $2500 \mathrm{~m}^{2}$, separated into centre (900-1000 $\mathrm{m}^{2}$ ) and periphery. A plan of the Höglwald experiments is given in Kreutzer and Weiss [26]. The stands were limed manually in April 1984 with sieves using $4 \mathrm{t} \mathrm{ha}^{-1}$ of fine $(90 \%<0.1 \mathrm{~mm})$ ground dolomitic limestone [21] resulting in inputs of $22 \mathrm{kmol} \mathrm{ha}^{-1} \mathrm{Ca}$ and $20 \mathrm{kmol} \mathrm{ha}^{-1} \mathrm{Mg}$. Irrigation was performed from Spring 1984 to Autumn 1990 with a sprinkler system. Each year between May and November, 15 to 18 irrigation events were carried out. The annual amount of irrigation was $170-180 \mathrm{~mm}$, which increased the natural throughfall input between May and November by about $50 \%$. Tap water was deionised and adjusted to rain water conductivity (10-20 $\left.\mu \mathrm{S} \mathrm{cm}^{-1}\right)$ through the addition of $\mathrm{Ca}\left(\mathrm{NO}_{3}\right)_{2}$ and $\mathrm{MgSO}_{4}$. For acid irrigation, a pH of approx. 2.6 was obtained through the addition of $\mathrm{H}_{2} \mathrm{SO}_{4}$.

\subsection{Sampling and chemical analysis}

Needles were collected in the dormant season from the upper third of the crown from randomly selected dominant trees by helicopter or tree climbers and sampled separately for the different treatments and needle age classes: current needles $(\mathrm{C})$, current plus one year old needles $(\mathrm{C}+1)$, and current plus two year old needles $(\mathrm{C}+2)$. After sampling, needles were dried at $65^{\circ} \mathrm{C}$. $\mathrm{N}$ was analysed with $\mathrm{CHN}$ (Leco). $\mathrm{P}, \mathrm{K}, \mathrm{Mg}, \mathrm{Ca}, \mathrm{Al}, \mathrm{Mn}$, and Fe were measured with ICP-OES (PerkinElmer) after dissolution with $\mathrm{HNO}_{3}(65 \%)$ for $12 \mathrm{~h}$ in pressure bombs $\left(165^{\circ} \mathrm{C}\right)$. Finally, dry mass of 100 -needle samples were determined. In 1990, 1991, 1997, and 2004 each tree and needle age class was analysed separately $(N=10)$, while in the other years a mixed sample was made for each needle age class and treatment from 6 to 10 trees from each treatment.

\subsection{Statistical methods}

Treatment effects for individually analysed needles were evaluated with a one-way ANOVA using the statistical package SPSS 11.01 for Windows (SPSS Inc.). Tukey test (equal variances), and Thamhane's T2 (unequal variances according to Levene statistics) were used as post-hoc tests. A critical probability level of 0.05 was used to indicate significant differences.

\section{RESULTS}

$\mathrm{N}$ was generally higher in the current $(\mathrm{C})$ (mean for all treatments: $\left.15.0 \mathrm{mg} \mathrm{g}^{-1}\right)$ than in the $\mathrm{C}+1\left(13.8 \mathrm{mg} \mathrm{g}^{-1}\right)$ and $\mathrm{C}+2$ (12.9 $\mathrm{mg} \mathrm{g}^{-1}$ ) needles (Fig. 1). According to the classification given in Table I, the status of the current needles represents a broad spectrum, which stretches from low to high, while average and high values dominate. No statistically significant differences (Tab. II) could be observed for any of the treatments.

High year to year variations were observed for P (Fig. 2), especially in the $\mathrm{C}$ needles, varying from very low to high levels. Generally, the $\mathrm{C}$ needles had higher $\mathrm{P}$ concentrations (average: $\left.1.6 \mathrm{mg} \mathrm{g}^{-1}\right)$ than the $\mathrm{C}+1\left(1.2 \mathrm{mg} \mathrm{g}^{-1}\right)$ and $\mathrm{C}+2$ $\left(1.1 \mathrm{mg} \mathrm{g}^{-1}\right)$ needles. Statistically significant effects were only found between some of the treatments in 2004 (see Tab. II). Figure 2 indicates a higher susceptibility for lower $\mathrm{P}$ concentrations on the limed treatments for the $\mathrm{C}+2$ and $\mathrm{C}+1$, but not for the $\mathrm{C}$ needles.

$\mathrm{K}$ showed very high variation between years (Fig. 3). The level varied from the categories "very low" to "high". C needles normally had higher levels $\left(4.3 \mathrm{mg} \mathrm{g}^{-1}\right)$ than $\mathrm{C}+1$ (3.9 $\mathrm{mg} \mathrm{g}^{-1}$ ), or $\mathrm{C}+2$ needles $\left(3.5 \mathrm{mg} \mathrm{g}^{-1}\right.$ ) (Fig. 3, Appendix for $\mathrm{C}+1$ values). No treatment effect could be observed during the whole investigation period.

Ca concentrations reached from low to high on the unlimed treatments and from average to very high on the limed treatments (Fig. 4, Appendix for $\mathrm{C}+1$ values). Ca was higher in the $\mathrm{C}+2$ needles $\left(5.6 \mathrm{mg} \mathrm{g}^{-1}\right.$ on the unlimed, $7.4 \mathrm{mg} \mathrm{g}^{-1}$ on the limed treatments), than in $\mathrm{C}+1$ ( $4.4 \mathrm{mg} \mathrm{g}^{-1}$ unlimed; $6.4 \mathrm{mg} \mathrm{g}^{-1}$ limed), or C (3.4 $\mathrm{mg} \mathrm{g}^{-1}$ unlimed; $4.3 \mathrm{mg} \mathrm{g}^{-1}$ limed). The highest difference occurred ten years after liming (1994) in the C+1 and C+2 needles between the limed and unlimed treatments.

$\mathrm{Mg}$ was only slightly affected by the treatments, but also shows very high year to year variations (Fig. 5, Appendix for $\mathrm{C}+1$ values). The $\mathrm{Mg}$ level for the current needles stretches 


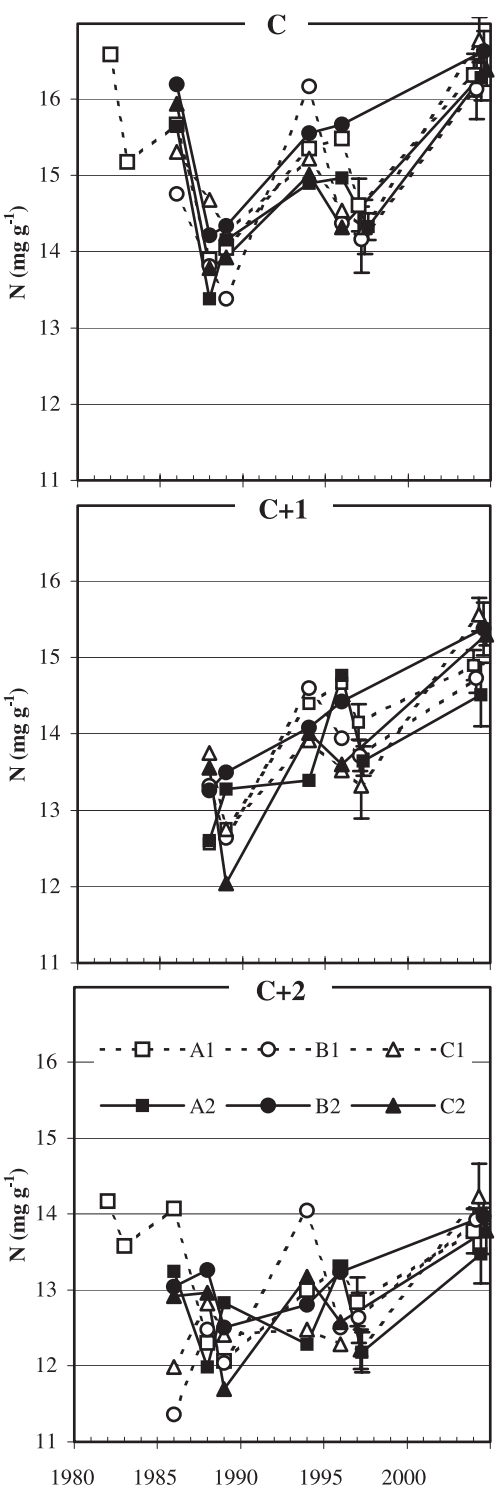

Figure 1. Mean $\mathrm{N}$ concentrations of current (C), current + one year $(\mathrm{C}+1)$, and current + two year needles $(\mathrm{C}+2)$ at the $\mathrm{A} 1$ (control), B1 (acid irrigation), C1 (normal irrigation), A2 (limed), B2 (limed + acid irrigation), and C2 (limed + normal irrigation) treatment. Liming was conducted in April 1984, irrigation was performed from Spring 1984 to Autumn 1990. Error bars representing the standard error are given when the needles of each tree were analysed individually. For characterising the nutritional level see Table I. No significant differences were found at $p<0.05$ (years analysed 1997, 2004).

from "very low" to "very high". Mean concentration was higher in the $\mathrm{C}\left(1.1 \mathrm{mg} \mathrm{g}^{-1}\right)$, than in the $\mathrm{C}+1\left(0.9 \mathrm{mg} \mathrm{g}^{-1}\right)$, or $\mathrm{C}+2$ needles $\left(0.7 \mathrm{mg} \mathrm{g}^{-1}\right)$.

Mn (Fig. 6, Appendix for $\mathrm{C}+1$ values) was higher in the $\mathrm{C}+2$ needles $\left(2.9 \mathrm{mg} \mathrm{g}^{-1}\right)$, than in $\mathrm{C}+1\left(2.4 \mathrm{mg} \mathrm{g}^{-1}\right)$, or $\mathrm{C}$ $\left(1.9 \mathrm{mg} \mathrm{g}^{-1}\right)$. Generally, the A2 treatment showed the lowest concentrations, while other limed treatments actually had the highest $\mathrm{Mn}$ concentrations (for example C2 in 2004). A high year to year variation could be observed for Fe (Fig. 7,

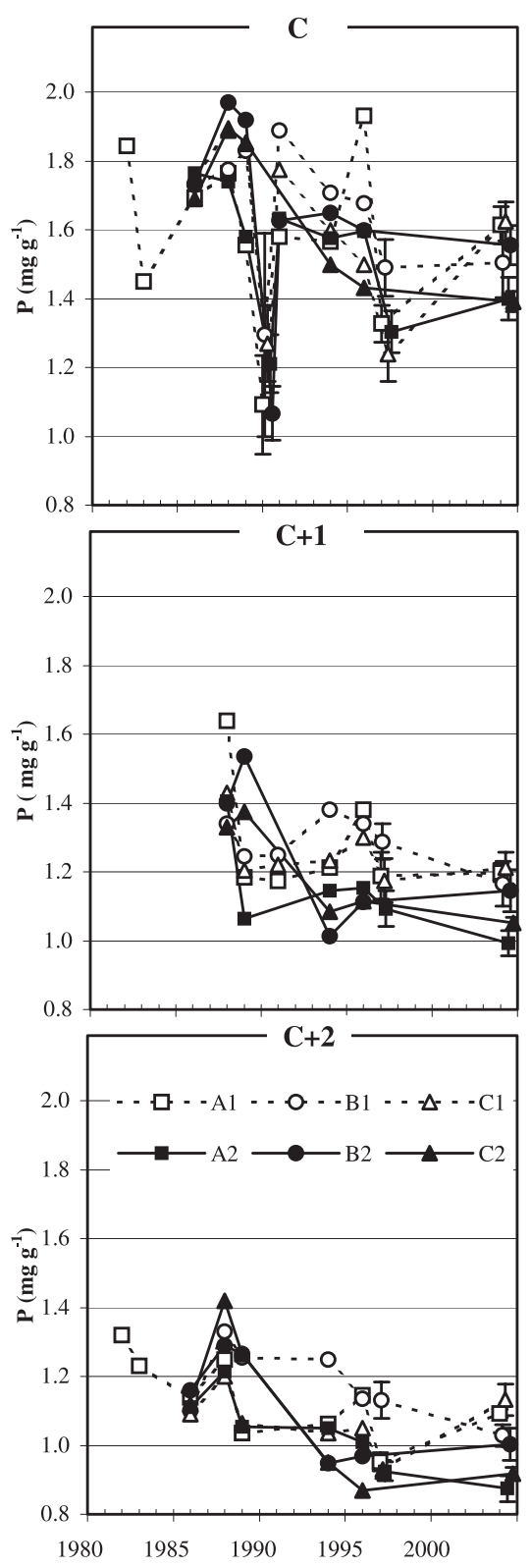

Figure 2. Mean $\mathrm{P}$ concentrations of current $(\mathrm{C})$, current + one year $(\mathrm{C}+1)$, and current + two year needles $(\mathrm{C}+2)$ at the different treatments. Error bars representing the standard error are given when the needles of each tree were analysed individually. For detailed information about the abbreviations and treatments see Figure 1. Statistically significant differences $(p<0.05)$ were found in 2004 (see Tab. II).

Appendix for $\mathrm{C}+1$ values), while the treatment effects were small.

$\mathrm{Al}$ was generally lower in the limed treatments (Fig. 8, Appendix for $\mathrm{C}+1$ values). However, due to a high spatial heterogeneity, the differences mostly lacked statical significance. Few data were available for the 100 needle dry weight (data not presented). Very high year to year variations could also be observed for this parameter, without clear treatment effect or trend. 
Table I. Foliar concentrations ( $\mathrm{mg} \mathrm{g}^{-1}$ ) characterising the nutritional level according to the classification of the German forest soil survey, based on [43] for current needles and current + two year old needles $(\mathrm{C}+2)$.

\begin{tabular}{lccccccccc}
\hline Level & $\mathrm{N}$ & $\mathrm{P}$ & $\mathrm{K}$ & $\mathrm{Ca}$ & $\mathrm{Mg}$ & $\mathrm{Mn}$ & $\mathrm{Fe}$ & $\begin{array}{c}\mathrm{Ca} \\
(\mathrm{C}+2)\end{array}$ & $\begin{array}{c}\mathrm{Mg} \\
(\mathrm{C}+2)\end{array}$ \\
\hline Very low & $<13$ & $<1.2$ & $<3.5$ & $<1.0$ & $<0.75$ & $<0.05$ & $<0.02$ & $<4.0$ & $<0.3$ \\
Low & $13-14$ & $1.2-1.4$ & $3.5-4.0$ & $1.0-2.0$ & $0.75-1.00$ & $0.05-1.0$ & $0.02-0.05$ & $4.0-5.0$ & $0.3-0.7$ \\
Average & $14-15$ & $1.4-1.8$ & $4.0-5.0$ & $2.0-3.0$ & $1.00-1.25$ & $1.0-2.0$ & $0.05-0.1$ & $5.0-7.5$ & $0.7-1.0$ \\
High & $15-17$ & $1.8-2.0$ & $5.0-7.0$ & $3.0-5.0$ & $1.25-1.50$ & $2.0-4.0$ & $0.1-0.5$ & $7.5-10.0$ & $1.0-1.25$ \\
Very high & $>17$ & $>2.0$ & $>7.0$ & $>5.0$ & $>1.50$ & $>4.0$ & $>0.5$ & $>10.0$ & $>1.25$ \\
\hline
\end{tabular}

Table II. Statistical differences for the needle age classes current $(\mathrm{C})$, current + one year $(\mathrm{C}+1)$, current + two year $(\mathrm{C}+2)$ between the treatments A1 (control), B1 (acid irrigation), C1 ( normal irrigation), A2 (liming), B2 (limed + acid irrigation), and C2 (liming + irrigation) for the years 1990 (only current needles), 1997, and 2004. Different letters in a row indicate a significant difference at $p<0.05$. The values of the concentrations are given in Figures 1-8. Note: for N, no data were available in 1990. When no information is given, no statistically significant difference was observed.

\begin{tabular}{|c|c|c|c|c|c|c|c|c|}
\hline Element & Year & Age class & A1 & B1 & $\mathrm{C} 1$ & $\mathrm{~A} 2$ & B2 & $\mathrm{C} 2$ \\
\hline \multirow[t]{3}{*}{$\bar{P}$} & 2004 & $\mathrm{C}$ & a & $\mathrm{ab}$ & $\mathrm{a}$ & $a b$ & $a b$ & $\mathrm{~b}$ \\
\hline & & $\mathrm{C}+1$ & $\mathrm{a}$ & $a b$ & $\mathrm{a}$ & $\mathrm{b}$ & $a b$ & $a b$ \\
\hline & & $\mathrm{C}+2$ & $\mathrm{a}$ & $a b$ & $\mathrm{a}$ & $\mathrm{b}$ & $a b$ & $\mathrm{~b}$ \\
\hline $\mathrm{Ca}$ & 1990, 1997 & $\mathrm{C}$ & $a b$ & $\mathrm{~b}$ & $a b$ & $\mathrm{a}$ & & \\
\hline $\mathrm{Mg}$ & 1990 & $\mathrm{C}$ & $a b$ & $a b$ & $\mathrm{~b}$ & a & & \\
\hline \multirow[t]{3}{*}{$\mathrm{Mn}$} & 1990 & $\mathrm{C}$ & $\mathrm{a}$ & $a b$ & $\mathrm{a}$ & $\mathrm{b}$ & & \\
\hline & 2004 & $\mathrm{C}+1$ & $a b$ & $a b$ & $a b$ & $\mathrm{~b}$ & $a b$ & $\mathrm{a}$ \\
\hline & & $\mathrm{C}+2$ & $\mathrm{~b}$ & $a b$ & b & $\mathrm{b}$ & $a b$ & a \\
\hline $\mathrm{Al}$ & 2004 & $\mathrm{C}+2$ & $a b$ & $a b$ & $a b$ & $\mathrm{~b}$ & $\mathrm{a}$ & $a b$ \\
\hline
\end{tabular}

\section{DISCUSSION}

The concentrations of $\mathrm{N}, \mathrm{P}, \mathrm{K}$, and $\mathrm{Mg}$ were generally higher in the current needles than in the older needles at the Höglwald site. The opposite was observed for $\mathrm{Ca}, \mathrm{Mn}$ and $\mathrm{Al}$, while the $\mathrm{Fe}$ concentrations were relatively similar. Spruce needles generally show this pattern for N, P, K and Ca [28]. For other elements, often no general tendency can be found or patterns arose from case to case. For example, Ingerslev [23] observed the same pattern for $\mathrm{N}, \mathrm{P}, \mathrm{K}$, and $\mathrm{Ca}$ while Mg concentrations were higher in the older needles of a Norway spruce plantation in Denmark. Due to the high input of sea salts from the North Sea [23], Mg was generally higher in this study compared with our data, and no reason is given for a translocation of $\mathrm{Mg}$ from older to younger needles.

Nearly all estimated elemental concentrations showed very high year to year variations, but low treatment effects. A wide year to year variation of elemental concentrations in needles seems to be usual in Central European, and Northern European Norway spruce stands [29]. However, the reasons for these variations remained unclear. Even though the stands at the Höglwald site exhibited years with "low" nutrient concentrations for some elements according to [43], they showed regularly high yearly increments [19]. We also observed a very high heterogeneity within the same treatments (see also [7,35]). Often small scale site effects, genetic differences, or weather conditions are suggested as reasons for the observed variations $[13,42]$. However, there is still a lack of detailed investigation about the reasons for the observed heterogeneity. Especially wide year to year variations were observed for $\mathrm{K}$ in the current needles at our site, or in a Swedish study [38], where a downward trend was thought to exist. However, our data show that the high year to year variations have to be considered when interpreting needle data, and a lot of repeated estimations are needed to show a real time trend. The K concentrations at the Höglwald site were mostly lower than at other spruce stands in Europe [29,43]. In some years the $\mathrm{K}$ concentrations at the Höglwald site were classified as "very low" [21,43] or "insufficient" [29], while a few years later the current needle $\mathrm{K}$ concentrations could be classified as "high". The regularly high yearly increment of the trees does not indicate deficiency of nutrients [19]. Long periods of drought are sometimes considered to be responsible for periodically low concentrations in K [42]. However, this seems not to be the case in our study, nor in the Swedish study [38]. Even irrigation in 1990 did not raise K in the current needles. No Ca-K antagonism could be observed on the limed treatments, while in another experiment [23] a risk of induced $\mathrm{K}$ deficiency following liming is indicated.

We found a relatively small variation in the $\mathrm{N}$ concentrations (also [35]), although other parameters of the $\mathrm{N}$-cycle (especially $\mathrm{NO}_{3}^{-}$) are highly variable at our site [20]. No luxurious supply with $\mathrm{N}$ could be found in 


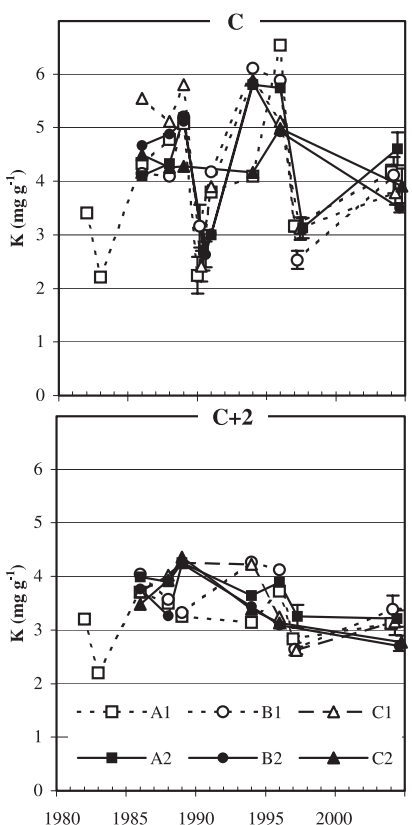

Figure 3. Mean $\mathrm{K}$ concentrations of current (C), and current + two year needles $(\mathrm{C}+2)$ at the different treatments. Error bars representing the standard error are given when the needles of each tree were analysed individually. For detailed information about the abbreviations and treatments see Figure 1. No significant differences were found at $p<0.05$ (years analysed 1990, 1997, 2004).

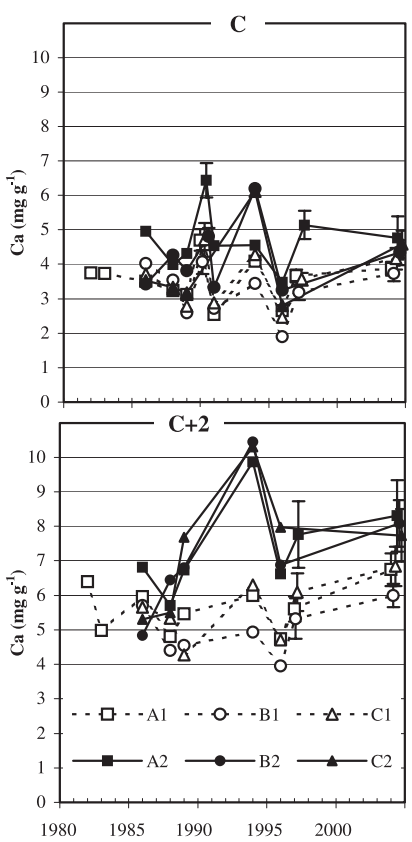

Figure 4. Mean Ca concentrations of current (C), and current + two year needles $(\mathrm{C}+2)$ at the different treatments. Error bars representing the standard error are given when the needles of each tree were analysed individually. For detailed information about the abbreviations and treatments see Figure 1. Statistically significant differences ( $p<0.05$ ) were found in 1990 and 1997 for current needles (see Tab. II).

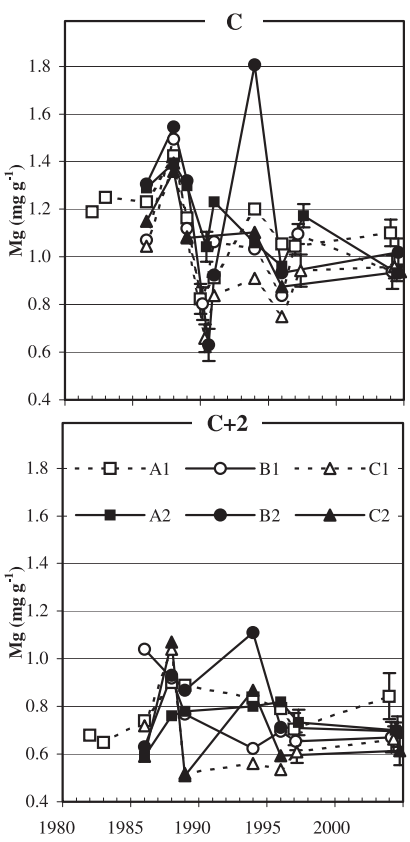

Figure 5. Mean $\mathrm{Mg}$ concentrations of current (C), and current + two year needles $(\mathrm{C}+2)$ at the different treatments. Error bars representing the standard error are given when the needles of each tree were analysed individually. For detailed information about the abbreviations and treatments see Figure 1. Statistically significant differences $(p<0.05)$ were found only in 1990 for current needles (see Tab. II).

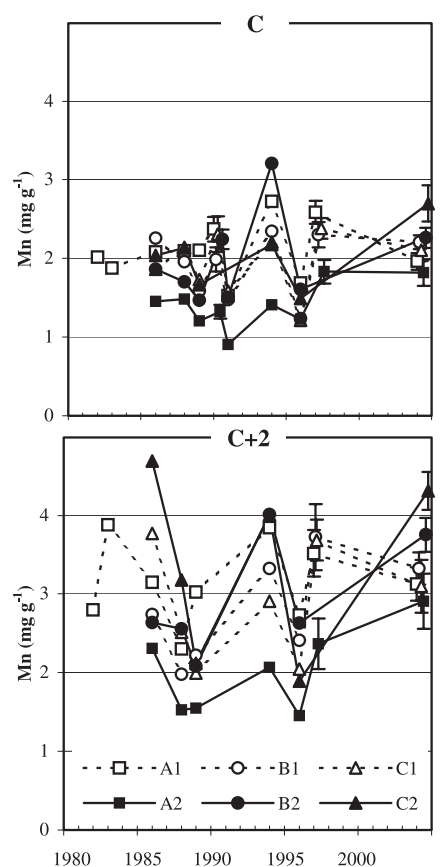

Figure 6. Mean Mn concentrations of current (C), and current + two year needles $(\mathrm{C}+2)$ at the different treatments. Error bars representing the standard error are given when the needles of each tree were analysed individually. For detailed information about the abbreviations and treatments see Figure 1. Statistically significant differences $(p<0.05)$ were found in 1990 and 2004 (see Tab. II). 


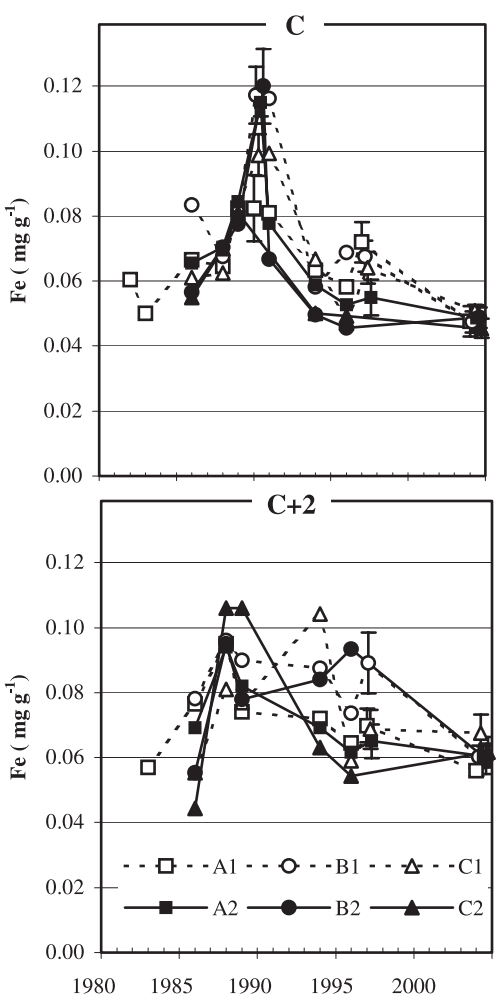

Figure 7. Mean Fe concentrations of current (C), and current + two year needles $(\mathrm{C}+2)$ at the different treatments. Error bars representing the standard error are given when the needles of each tree were analysed individually. For detailed information about the abbreviations and treatments see Figure 1. No significant differences were found at $p<0.05$ (years analysed 1990, 1997, 2004).

the youngest needles. In contrast to this observation, Aber et al. [1] assumed that a linear increase in foliar $\mathrm{N}$ would occur in N-saturated stands. However, even fertilisation with $\mathrm{N}$ fertilizers did not increase $\mathrm{N}$ concentrations in the needles at the Höglwald to a significant extent [19]. At our site it could be shown that the $\mathrm{NO}_{3}^{-}$uptake of fine roots of spruce can effectively be regulated by the trees [11], and the excess $\mathrm{N}$-input is nearly completely leaving the ecosystem as nitrate through seepage, or as $\mathrm{N}$-trace gases $[6,20,34]$.

Some impairment of the $\mathrm{P}$-availability after liming is indicated by the lower $\mathrm{P}$-concentrations in $\mathrm{C}+1$ and $\mathrm{C}+2$ needles in 2004. Changes in the humus layer after liming may be responsible for it. In a further liming experiment at the Höglwald site, Huber [16] observed a decrease in phosphate concentration in soil solution taken directly below the humus layer within the first two years after liming. The $\mathrm{P}$ availability for fine roots may be impaired by the elevated soil fixing capacity in the surface humus after liming due to the enhanced $\mathrm{Ca}, \mathrm{Al}$ and Fe content of the surface humus [26]. P has low chemical solubility in the soil solution at high concentrations of $\mathrm{Ca}$, which was applied with the lime, and tends to precipitate as Ca-phosphate $[3,5]$. Liming also caused a change of the humus morphology due to earthworm activity (see Kreutzer [25]). From below, mineral material was mixed into a newly formed

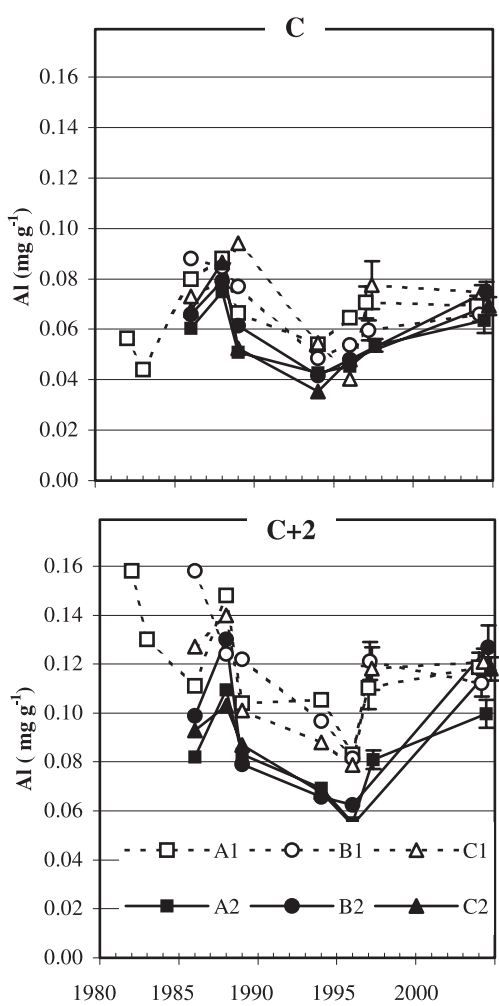

Figure 8. Mean $\mathrm{Al}$ concentrations of current (C), and current + two year needles $(\mathrm{C}+2)$ at the different treatments. Error bars representing the standard error are given when the needles of each tree were analysed individually. For detailed information about the abbreviations and treatments see Figure 1. Statistically significant differences $(p<0.05)$ were found only in 2004 for $\mathrm{C}+2$ needles (see Tab. II).

Olu (lu from Lumbricus) horizon. This enhanced the Fe and $\mathrm{Al}$ content of the surface humus. According to investigations by Pare and Bernier [33], Fe and Al at the soil surface are negatively correlated with foliar P concentrations. This was especially the case when amorphous or low crystalline oxides with their high phosphate fixing capacity were present. In the case of the Höglwald, where a surface humus layer remained after liming, organic $\mathrm{Fe}$ or $\mathrm{Al}$ mixtures may also be relevant for the decreased P-availability. Gerke and Hermann [10] could show that the P-sorption capacity of organic-Fe substance mixtures was even six to seven times larger than that of amorphous $\mathrm{Fe}$ oxides. However, in contrast to the older needles, the current year $\mathrm{P}$ concentrations at the limed treatments are still at an average level for German spruce trees [43]. This fact indicates a well functioning relocation of $\mathrm{P}$ from older to younger needles.

The limed treatments showed regularly, but mostly nonsignificantly higher $\mathrm{Ca}$ concentrations. The differences between limed and unlimed treatments were most pronounced in the older needles circa ten years after liming. A significant liming effect was found in a Swedish study six to seven years after liming [37]. Liming increased the Ca content of the roots at the Höglwald [15], as in other liming [8] or wood ash [9] experiments, more distinctly than that of needles. A high proportion 
of Ca may be immobilised in the root apoplast, and there prevented from being transported to the needles [9]. The physiological need for $\mathrm{Ca}$ in conifers is relatively low, and only ca. $1.2 \mathrm{mg} \mathrm{g}^{-1} \mathrm{Ca}$ is needed to prevent the needles from deficiency [12]. At a level of $2 \mathrm{mg} \mathrm{g}^{-1} \mathrm{Ca}$, additional $\mathrm{Ca}$ is nearly totally converted to Ca-oxalat, which is of low physiological value. The acid irrigated plot often showed the lowest $\mathrm{Ca}$ concentration in needles (not significant) and roots [15], but $\mathrm{Ca}$ was still above the deficiency threshold [19].

No clear treatment effects on the $\mathrm{Mg}$ concentrations were detected at our site, while the year to year variations were high. Liming may be more effective on $\mathrm{Mg}$ deficient sites [30]. However, the simultaneous application of $\mathrm{Ca}$ may impede an effective $\mathrm{Mg}$ uptake due to ion antagonism.

Al concentrations were lower on the limed treatment over a relatively long period. However, the high increment at our site indicates no Al toxicity, and demonstrates effective stress tolerance and stress avoidance strategies of the trees [19]. A significant decrease of $\mathrm{Al}$ concentrations in needles was shown in another liming experiment [30], but the differences between the investigation years was more pronounced than between the treatments.

Acid irrigation had very limited effects on the elemental concentrations in the needles. Acid irrigation resulted in longlasting higher $\mathrm{SO}_{4}^{2-}$ concentrations in seepage water. Together with $\mathrm{SO}_{4}^{2-} \mathrm{Al}, \mathrm{Mg}$ and $\mathrm{Ca}$ were leached from the main rooting zone, but the uptake of $\mathrm{Ca}$ and $\mathrm{Mg}$ from deeper soil horizons may have counteracted these losses [19]. The elemental concentrations of fine roots recovered relatively rapidly from acid irrigation. $\mathrm{Ca}$ and $\mathrm{Mg}$ contents of the roots in the main rooting zone were decreased during the irrigation period, but two years after the acidification experiment had been terminated, no difference could be found [15]. Even the enormously elevated $\mathrm{Al}$ concentrations in soil water did not influence root growth at our site [14]. Al content of the roots was not increased by acid irrigation [15]. Effective avoidance strategies for the protection against $\mathrm{Al}$ poisoning may exist for spruce at the Höglwald site [19,25].

\section{CONCLUSIONS}

Even a healthy, vigorously growing mature spruce stand shows "deficient" nutrient levels, and high yearly variations in concentrations from time to time. This has to be considered when interpreting needle analysis. Liming had relatively small effects on the needle chemistry. This was also shown in spruce stands in south-western Sweden [37]. The elevated Ca concentrations after liming have no physiological value for the trees at our site, while the recently observed reduction in $\mathrm{P}$ concentration needs attention. The $\mathrm{N}$ concentrations are not good indices for $\mathrm{N}$-saturation, because the trees are able to protect the needles from oversupply.

Acknowledgements: Research was funded by the Bundesministerium für Bildung und Forschung (BMBF), Berlin, and the Bayerische Staatsministerium für Landwirtschaft und Forsten, München (last contract number B64). We thank the resident master student
Daniel Ross from Britain for proof-reading the manuscript, and two anonymous reviewers for their comments on improving the manuscript.

\section{REFERENCES}

[1] Aber J., McDowell W., Nadelhoffer K., Magill A., Berntson G., Kamakea M., McNulty S., Currie W., Rustad L., Fernandez I., Nitrogen saturation in temperate forest ecosystems. Hypotheses revisited, BioScience 48 (1998) 921-934.

[2] Alewell C., Manderscheid B., Gerstberger P., Matzner E., Effects of reduced atmospheric deposition on soil solution chemistry and elemental contents of spruce needles in NE-Bavaria, Germany, J. Plant Nutr. Soil Sci. 163 (2000) 509-516.

[3] Arvidsson H., Lundkvist H., Needle chemistry in young Norway spruce stands after application of crushed wood ash, Plant Soil 238 (2002) 159-174.

[4] Bonneau M., Evolution of the mineral fertility of an acidic soil during a period of ten years in the Vosges mountains (France). Impact of humus mineralisation, Ann. For. Sci. 62 (2005) 253-260.

[5] Burke M.K., Raynal D., Liming influences growth and nutrient balances in sugar maple (Acer saccharum) seedlings on an acidic forest soil, Environ. Exp. Bot. 39 (1998) 105-116.

[6] Butterbach-Bahl K., Gasche R., Huber C., Kreutzer K., Papen H., Impact of $\mathrm{N}$ input by wet deposition on $\mathrm{N}$-trace gas fluxes and $\mathrm{CH}_{4}$-oxidation in spruce forest ecosystems of the temperate zone in Europe, Atmos. Environ. 32 (1998) 559-564.

[7] Cheaïb A., Mollier A., Thunt S., Lambrot C., Pellerin S., Loustau D., Interactive effects of phosphorus and light availability on early growth of maritime pine seedlings, Ann. For. Sci. 62 (2005) 575583.

[8] Feger K.H., Raspe S., Zöttl H.W., Veränderung des Ernährungszustandes nach Düngung, in: Raspe S., Feger K.H., Zöttl H.W. (Eds.), Ökosystemforschung im Schwarzwald, Ecomed, Landsberg, 1998, pp. 394-409.

[9] Genenger M., Zimmermann S., Hallenbartner D., Landolt W. Frossard E., Brunner I., Fine root growth and element concentrations of Norway spruce as affected by wood ash and liquid fertilisation, Plant Soil 255 (2003) 253-264.

[10] Gerke J., Hermann R., Adsorption of orthophosphate to humic Fe-complexes and to amorphous Fe-oxide, Z. Pflanzenernär. Bodenkund. 155 (1992) 233-236.

[11] Gessler A., Schneider S., von Sengbusch D., Weber P., Hanemann U., Huber C., Rothe A., Kreutzer K., Rennenberg H., Field and laboratory experiments on net uptake of nitrate and ammonium by the roots of spruce (Picea abies) and beech (Fagus sylvatica) trees, New Phytol. 138 (1998) 275-285.

[12] Gülpen M., Türk S., Fink S., Ca nutrition of conifers, Z. Pflanzenernähr. Bodenk. 158 (1995) 519-527.

[13] Hagen-Thorn A., Armolaitis K., Callesen I., Stjernquist I., Macronutrients in tree stems and foliage: a comparative study of six temperate forest species planted at the same site, Ann. For. Sci. 61 (2004) 489-498.

[14] Hahn G., Marschner H., Effect of acid irrigation and liming on root growth of Norway spruce, Plant Soil 199 (1998) 11-22.

[15] Hahn G., Marschner H., Cation concentration of short roots of Norway spruce as affected by acid irrigation and liming, Plant Soil 199 (1998) 23-27.

[16] Huber C., Untersuchungen zur Ammoniakimmission und zum Stoffhaushalt auf ungekalkten und neugekalkten Flächen in einem stickstoffgesättigten Fichtenökosystem (Höglwald), Hieronymus, München, 1997.

[17] Huber C., Kreutzer K., Three years of continuous measurements of atmospheric ammonia concentrations over a forest stand at the Höglwald site in southern Bavaria, Plant Soil 240 (2002) 13-22. 
[18] Huber C., Oberhauser A., Kreutzer K., Deposition of ammonia to the forest floor under spruce and beech at the Höglwald site, Plant Soil 240 (2002) 3-11.

[19] Huber C., Kreutzer K., Röhle H., Rothe A., Response of artificial acid irrigation, liming, and $\mathrm{N}$-fertilisation on elemental concentrations in needles, litter fluxes, volume increment, and crown transparency of an $\mathrm{N}$ saturated Norway spruce stand, For. Ecol. Manage. 200 (2004) 3-21.

[20] Huber C., Weis W., Baumgarten M., Göttlein A., Spatial and temporal variation of seepage water chemistry after femel and small scale clear-cutting in a N-saturated Norway spruce stand, Plant Soil 267 (2004) 23-40.

[21] Hüttl R.F., Die Nährelementversorgung geschädigter Wälder in Europa und Nordamerika, Freiburger Bodenkundl. Abhandl. 28 (1991).

[22] Hüttl R.F., Schneider B.U., Forest ecosystem degradation and rehabilitation, Ecol. Eng. 10 (1998) 19-31.

[23] Ingerslev M., Above ground biomass and nutrient distribution in a limed and fertilized Norway spruce (Picea abies) plantation, Part I, Nutrient concentrations, For. Ecol. Manage. 119 (1999) 21-38.

[24] Ingerslev M., Mälkonen E., Nilsen P., Nohrstedt H.-Ö., Oskarsson H., Raulund-Rasmussen K., Main findings and future challenges in forest nutritional research and management in the Nordic countries, Scand. J. For. Res. 16 (2001) 488-501.

[25] Kreutzer K., Effects of forest liming on soil processes, Plant Soil 168-169 (1995) 447-470.

[26] Kreutzer K., Weiss T., The Höglwald field experiment - aims, concept and basic data, Plant Soil 199 (1998) 1-10.

[27] Lundström U.S., Bain D.C., Taylor A.F.S., van Hees P.A.W., Effects of acidification and its mitigation with lime and wood ash on forest soil processes: a review, Water Air Soil Pollut. Focus 3 (2003) 5-28.

[28] Lyr H., Fiedler H.J., Tranquillini W. (Eds.), Physiologie und Ökologie der Gehölze, Gustav Fischer, Jena, 1992.

[29] Mellert K.H., Prietzel J., Straussberger R., Rehfuess K.E., Longterm nutritional trends of conifer stands in Europe: results from the RECOGNITION project, Eur. J. Forest. Res. 123 (2004) 305-319.

[30] Misson L., Ponette Q., Andrë F., Regional scale effects on base cation fertilization on Norway spruce and European beech stands situated on acid brown soils: soil and foliar chemistry, Ann. For Sci. 58 (2001) 699-712.

[31] Nilsen P., Fertilization experiments on forest mineral soils: a review of the Norwegian results, Scand. J. For. Res. 16 (2001) 541-554.
[32] Nohrstedt H.-Ö., Response of coniferous forest ecosystems on mineral soils to nutrient additions: a review of Swedish Experiences, Scand. J. For. Res 16 (2001) 555-573.

[33] Pare D., Bernier B., Origin of the phosphorus deficiency observed in declining sugar maple stands in the Quebec Appalachians, Can. J. For. Res. 19 (1989) 24-34.

[34] Rothe A., Huber C., Kreutzer K., Weis W., Deposition and soil leaching in stands of Norway spruce and European beech: results from the Höglwald research in comparison with other case studies, Plant Soil 240 (2002) 33-45.

[35] Rothe A., Ewald J., Hibbs D.E., Do admixed broadleaves improve foliar nutrient status of conifer tree crops? For. Ecol. Manage. 172 (2003) 327-338.

[36] Saarsalmi A., Mälkönen E., Forest fertilisation research in Finland: A literature review, Scand. J. For. Res. 16 (2001) 514-535.

[37] Sikström U., Effects of liming and fertilization (N, PK) on stem growth, crown transparency, and needle element concentrations of Picea abies stands in southwestern Sweden, Can. J. For. Res. 32. (2002), 1717-1727.

[38] Thelin G., Rosengren-Brinck U., Nihlgård B., Barkman A., Trends in needle and soil chemistry of Norway spruce and Scots pine stands in South Sweden 1985-1994, Environ. Pollut. 99 (1998) 149-158.

[39] Ulrich B., Die Wälder in Mitteleuropa: Meßergebnisse ihrer Umweltbelastung, Theorie ihrer Gefährdung, Prognose ihrer Entwicklung, Vortrag vor dem Deutschen Forstverein am 24.9.1980, Allg. Forst Zeits. 44 (1980) 1198-1202.

[40] Ulrich B., Mayer R., Khanna P.K., Die Deposition von Luftverunreinigungen und ihre Auswirkungen in Waldökosystemen im Solling, Schriften Forstl. Fak. Univ. Göttingen 58, Sauerländer Verlag, Frankfurt, 1979, pp. 258-260.

[41] Vejre H., Ingerslev M., Raulund-Rasmussen K., Fertilization of Danish forests: a review of experiments, Scand. J. For. Res. 16 (2001) 502-513.

[42] Von Wilpert K., Lukes M., Ecochemical effects of phonolite rock powder, dolomite and potassium sulfate in a spruce stand on an acidified glacial loam, Nutr. Cycl. Agroecosyst. 65 (2003) 115-127.

[43] Wolff B., Rieck W., Baritz R., Hennig P., Deutscher Waldbodenbericht 1996, Band 1. Bundesministerium für Ernährung, Landwirtschaft und Forsten, 1999. 
APPENDIX. Mean $\mathrm{K}, \mathrm{Ca}, \mathrm{Mg}, \mathrm{Mn}, \mathrm{Fe}$ and $\mathrm{Al}$ concentrations of current + one year $(\mathrm{C}+1)$.
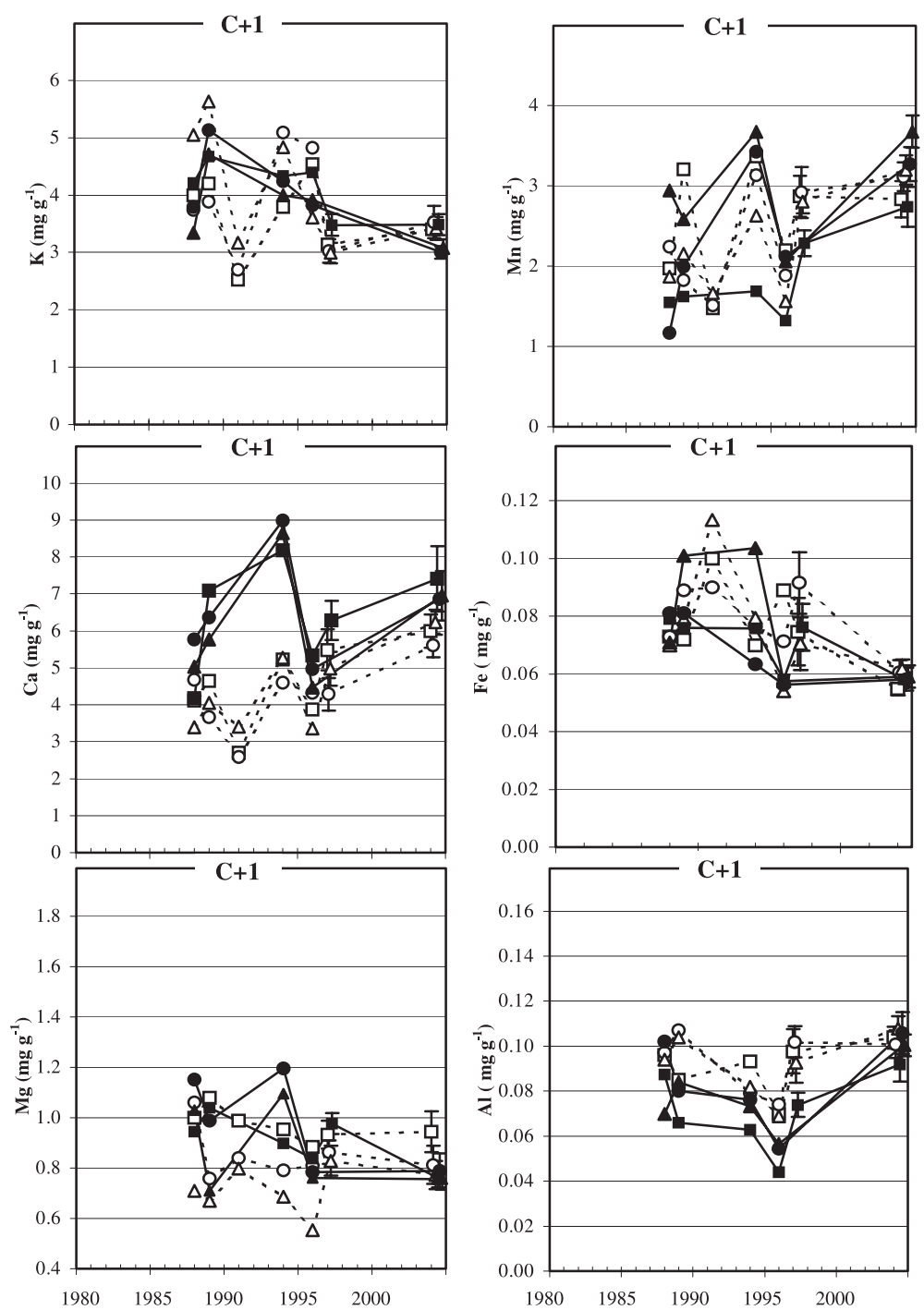